\title{
On the measurement of retail marketing mix effects in the presence of different economic regimes *
}

\author{
B. BODE, J. KOERTS and A.R. THURIK
}

This study deals with the measurement of the effects of retail marketing instruments on annual sales in retail stores. We assume that the sales level in retail stores is determined by an interplay of supply capacity and demand factors. In some stores sales are supply-determined, whereas in other stores sales are demand-determined. If it is not known a priori what economic regime applies, the more traditional approaches lead to biased estimation results. Therefore, a switching regression model is proposed to estimate the marketing mix effects.

Our ideas are tested using data from four different types of stores in the Dutch retail trade and a comparison is made with a more traditional approach. The main conclusions are: the traditional approach leads to underestimation of the marketing

Ben Bode is a Research Associate at the Econometric Institute, and an Assistant Professor of Statistics in the Rotterdam School of Management at Erasmus University Rotterdam (E.U.R.), P.O. Box 1738, 3000 DR Rotterdam, The Netherlands.

Johan Koerts is a Professor of Mathematical Statistics at the Econometric Institute at Erasmus University Rotterdam (E.U.R.), P.O. Box 1738, 3000 DR Rotterdam, The Netherlands.

Roy Thurik is head of the Department of Fundamental Research at the Research Institute for Small and Medium-Sized Business (R.I.S.M.B.), P.O. Box 7001, 2701 AA Zoetermeer, The Netherlands, and a Professor of Small Business Economics at the Econometric Institute at Erasmus University Rotterdam (E.U.R.), P.O. Box 1738, 3000 DR Rotterdam, The Netherlands.

* This study is part of a project carried out by the work group Fundamental Research in S.M.B. of the Econometric Institute of the E.U.R., and is supported by the Foundation for the Promotion of Research in Economic Sciences (Ecozoek), which is part of the Netherlands Organization of Scientific Research (N.W.O.). The authors wish to thank Jan van Dalen of E.U.R., who wrote the computer program for the estimation of the model parameters. In addition, they wish to acknowledge support in the composition of the data given by Kees Bakker of the Research Institute for Small and Medium-Sized Business in Zoetermeer, The Netherlands.

Intern. J. of Research in Marketing 5 (1988) 107-123

North-Holland mix effects. A switching regression model seems to be a promising instrument for analyzing these effects. The method has a wider applicability than the retail trade.

\section{Introduction}

This paper deals with the measurement of the effects of retail marketing instruments on annual store sales. The effects of marketing instruments have been analysed in a number of ways, in various contexts and at different aggregation levels. In a study of marketing generalizations Leone and Schultz (1980) present a list of studies that give rather broad and general support to the proposition that selective advertising has a direct and positive influence on individual company (brand) sales for particular markets and particular brands. The majority of the studies on advertising supporting this proposition employed simple regression analysis. However, simultaneous models were also introduced (sec for cxample Bass and Parsons (1969)).

The fact that rather broad and general support is given for the abovementioned proposition does not mean that insignificant or even negative relationships do not appear in studies on advertising effectiveness. For example, Sexton (1970) reports both positive and negative results of advertising on sales and most of the coefficients are not significant. Moreover, Curhan (1974), who studied the effects of newspaper advertising on selected fruits and vegetables, finds signifi- 
cant results for hard fruit and cooking vegetables, but not for salad vegetables or soft fruit. Another example of differences with respect to the effect of a marketing instrument can be found in Farris and Albion (1980). Their paper summarizes studies that have explicitly examined the effect of advertising on price sensitivity of demand. It appears that advertising may increase but also decrease price elasticity. According to Gatignon (1984) these opposing effects may occur because of an often overlooked moderating variable, viz., competitive reaction. His remark stresses the importance of a proper model specification when studying marketing mix effects.

According to Parsons and Schultz (1976: 39-40) there are five elements that an ideal sales response function should include: marketing mix interaction effects, carryover effects, competitive effects, simultaneous relationships and dimensions of decisions. However, there are very few studies in which all these elements are part of the model, usually because of lack of data. But even if all these five elements are included, the measurement of the effects of (retail store) marketing instruments may be incorrect. For one should realize that the sales level in stores is determined by an interplay of supply capacity and demand. As a consequence, we believe that it is perfectly possible that in some stores, at the moment of sample observation, sales are supply-determined (i.e., demand is large enough), whereas in other stores sales are demand-determined (i.e., demand is smaller than store capacity). ${ }^{1}$ If this is the case a classical regression approach to analyse store demand level with the aid of factors from the marketing mix leads to biased estimation results due to the fact that actual demand ex-

\footnotetext{
1 This was also found empirically. In a cross-section survey held in 1987 among Dutch confectioner's stores, about 65\% of the respondents answered to be in an excess supply regime, $30 \%$ in an excess demand regime, and about 5\% answered that they were in an equilibrium situation.
}

ceeds store capacity in some stores so that the direct measurement of their influence is frustrated. This problem cannot be overcome by using a classical simultaneous model in order to account for simultaneous effects, for there simply is no equilibrium at the individual store level.

Therefore, we propose to make use of a so-called 'switching model', in which sales are either supply-determined or demand-determined. If information is available regarding the regime to which each individual store belongs, the sample can a priori be divided into stores that are demand-determined and stores that are supply-determined. Usually one does not know a priori which of the two economic regimes applies to each of the available observations. Hence, we have to include both possibilities in the model, leaving the data to decide on the most likely regime distribution.

Switching models with endogenous regime choice have mainly been used to analyse markets in disequilibrium, where transactions are assumed to equal the minimum of supply and demand. See, for example, Rosen and Quandt (1978), Fair and Jaffee (1972) and Laffont and Garcia (1977), for an analysis of the labour market, the housing market and the credit market, respectively. All these models make use of aggregate time series data. In Kooiman, Van Dijk and Thurik (1985) a switching model is presented to analyse differences in floorspace productivity among retail stores in the grocery trade. See also Thurik and Kooiman (1986) for a less technical exposition. Their study makes use of a crosssection sample of individual stores. A further analysis with this model is given in Van Dalen, Koerts and Thurik (1987).

The purpose of our paper is to demonstrate that a switching model is an appropriate instrument for analyzing marketing mix effects in stores, and that a traditional regression approach leads to underestimation of these effects. The analysis will be carried out for 
retail stores. There are two important reasons to do so. Firstly, a retail store forms the final link in the distribution channel. Therefore, it is here that we can expect the most striking effects of marketing instruments. This is in accordance with Farris and Albion (1980: 27), who remark: 'The case for advertising as a contributor to price competition and a source of consumer information has becn made more convincingly in the retail sector than anywhere else'. Secondly, it is also here that supply restrictions are very crucial. In general, manufacturers or wholesalers are more able to cope with capacity constraints.

We shall make use of a model that resembles in certain aspects the models developed by Kooiman, Van Dijk and Thurik (1985) and Van Dalen, Koerts and Thurik (1987), but compared with Kooiman et al. our model is more complete: we take into account the effects of several variables from te marketing mix that were not part of Kooiman's model, such as advertising, service and location. In addition, our study has a broader empirical basis; in Kooiman et al. only one type of store is used, whereas we will consider four different types of stores. Compared with Van Dalen et al. (and also Kooiman et al.) we drop the hypothesis that storekeepers try to maximize the value of annual sales by partitioning total floorspace into selling area and remaining space. The first reason is economic: this hypothesis may be too strong, at least in the short run. It may very well occur that in a cross-section sample a large number of retail stores do not operate optimally, as far as the partitioning of floorspace is considered. The second reason is technical: it is possible that, due to the maximization hypothesis, the variable 'selling area' (which then becomes endogenous) technically plays a too dominant role in the model. This may influence the estimation results, and, in particular, the estimation of the regime distribution. As the aim of this paper is to demonstrate that a switching model as such should be preferable to a single equation model, we do not want our results to be disturbed by the maximization hypothesis.

The outline of this study is as follows: in section 2 the model is briefly described. Section 3 deals with the estimation method and the data. In section 4 the results are presented and a comparison is made with a traditional regression model. Section 5, finally, contains some concluding remarks and notes on further research.

\section{The model}

In its general form our model reads ${ }^{2}$

$$
\begin{aligned}
Q^{\mathrm{d}} & =Q^{\mathrm{d}}\left(C, X^{\mathrm{d}}\right) \\
Q^{\mathrm{s}} & =Q^{\mathrm{s}}\left(C, W, X^{\mathrm{s}}\right) \\
Q & =\min \left(Q^{\mathrm{d}}, Q^{\mathrm{s}}\right),
\end{aligned}
$$

where

$Q^{\mathrm{d}}=$ value of annual store's demand,

$Q^{\text {s }}=$ value of annual store's supply capacity,

$Q=$ realized annual sales value,

$C=$ store's selling area,

$W=$ store's total floorspace,

$X^{\mathrm{d}}=$ other demand factors, and

$X^{\mathrm{s}}=$ other supply factors.

The demand equation is specified as follows:

$Q^{\mathrm{d}}=\exp \left(\delta_{0}+\delta_{1} F\right)(1+M)^{1+\delta_{2}}(C-\gamma)^{v\left(X^{c}\right)}$,

with $v\left(X^{c}\right)=v_{0}+v_{a} A+v_{s} S+\delta_{f s} F s+\delta_{r g} R g$,

\footnotetext{
2 Kiefer argues that there is no reason to think that transactions are the minimum of supply and demand, unless this represents the outcome of some sort of unspecified rationing procedure (see Kiefer $(1980: 637)$ ). It is our opinion, however, that this argument does not hold in our situation. The supply side of our model is in fact a technical restriction: it represents the (supply) capacity of the store. Our model should be interpreted as follows: the storekeeper tries to meet annual demand $\left(Q^{\mathrm{d}}\right)$, given his store capacity $\left(Q^{\mathrm{s}}\right)$. Therefore, the actual sales value $(Q)$ is the minimum of $Q^{\mathrm{d}}$ and $Q^{\text {s. }}$.
} 
where

$F=$ share in total sales value of a specific assortment group (depending on the type of stores considered),

$M=$ fractional gross margin $(Q-I) / I$, with $I$ the store's purchasing value of annual sales,

$A=$ store's annual advertising expenses,

$S=$ service, measured as labour volume per square metre of total floorspace,

$R g=$ dummy region; equals one for stores located in densely populated areas, zero otherwise, and

$F s=$ dummy shopping centre; equals one for stores located in large shopping centres, zero otherwise.

The supply capacity equation is specified as follows:

$$
\begin{aligned}
Q^{s}= & \exp \left(\beta_{0}\right)(1+M) H^{\beta_{1}}(C-\gamma)^{\pi \epsilon} \\
& \times(W-C)^{(1-\pi) \epsilon},
\end{aligned}
$$

where $H=$ occupancy costs per square metre of total floorspace.

The rationale behind these relationships is the following: ${ }^{3}$

\subsection{The demand equation}

The level of demand is supposed to depend on

- The assortment: The store's assortment composition affects the volume of demand. For example, the presence of fresh products in supermarkets is supposed to increase the demand for products.

- The advertising expenses: Obviously, demand will be stimulated by advertising efforts.

- The price: The price level of the products sold is also an important factor in describ-

${ }^{3}$ See also Kooiman et al. (1985) for the specification of the demand equation, and Thurik and Koerts (1984a, b) for the specification of the supply capacity equation. ing the level of demand. In the data sets to be used, however, we do not observe price ( $p$ ) and volume $(q)$ separately, where $Q$ is defined as $Q=p q$. Therefore, following Kooiman et al., we decide to measure prices by $(1+M)$, where $M$ is the fractional gross margin $(Q-I) / I$. It follows that $(1+M)$ equals $Q / I$. Its role in the demand equation is both to transform the value of sales $Q$ into its volume, which is supposed to be proportional to the purchasing value $I$, and to represent the effect of pricing on the volume of demand (with price elasticity $\left.\delta_{2}\right)$.

- The store size: A relatively large store indicates a wide and deep assortment. A large number of products is offered, which influences demand positively. The store size is measured by selling area. The threshold $\gamma$ is introduced to investigate whether there is a minimum required selling area below which volume of demand is zero (cf. Nooteboom (1982), Thurik and Kleijweg (1986) and Nooteboom (1987)).

The shopping centre: If the store is located in a large shopping centre, demand is higher due to the attraction of many potential buyers.

- The service: The amount of service supplied by personnel is supposed to stimulate demand. The service is approximated by total labour volume per square metre of total floorspace.

- The population density: If the store is located in a densely populated area, demand is higher due to a large number of potential buyers. However, we have to be careful in drawing this conclusion as we do not correct for the intensity of competition within this analysis. The same holds true with respect to the interpretation of the shopping centre effect.

The multiplicative specification in eq. (2) is chosen to reflect that the effect of one variable on the level of demand depends on the 
level of other variables. The $\exp ($.$) function is$ introduced to avoid that the demand equation becomes zero when $F$ is zero. ${ }^{4}$

\subsection{The supply equations}

It is assumed that total floorspace, and its partitioning into selling area and remaining space, play a predominant role in the determination of supply. Following Thurik and Koerts (1984a,b) a beta-type specification is chosen. According to eq. (3) supply is zero when selling area does not surpass a threshold level $\gamma$, or when remaining space is zero. The parameter $\pi$ in the supply equation denotes the distribution between $C$ and $W-$ $C$, and the parameter $\epsilon$ denotes the scale elasticity.

The shift factor $\beta$, which can be used to denote efficiency, is a function of occupancy costs per unit of floorspace: $\beta=\exp \left(\beta_{0}\right) H^{\beta_{1}}$. We assume that floorspace is used more efficiently, when costs are high.

Finally, also the supply equation contains the term $(1+M)$ to transform the value of sales into its volume. In this study an additional effect of pricing on the volume of supply capacity, comparable with $\delta_{2}$ in eq. (2), is considered negligible.

\section{Estimation method and data}

Following Kooiman, Van Dijk and Thurik (1985) we add multiplicative disturbance terms to the demand and supply equations in (1):

$$
\begin{aligned}
& Q^{\mathrm{d}}=Q^{\mathrm{d}}\left(C, X^{\mathrm{d}}\right) \exp \left(\epsilon^{\mathrm{d}}\right), \\
& Q^{\mathrm{s}}=Q^{\mathrm{s}}\left(C, W, X^{\mathrm{s}}\right) \exp \left(\epsilon^{\mathrm{s}}\right), \\
& Q=\min \left(Q^{\mathrm{d}}, Q^{\mathrm{s}}\right) .
\end{aligned}
$$

\footnotetext{
${ }^{4}$ Specification (2) is almost equivalent to the second demand specification in Van Dalen et al. (cf. eq. (3.4)). In this study two different demand specifications were tested, but only the second one gave reasonable estimation results. For that reason we choose relationship (2) as our demand function.
}

As is usually done in this type of models we assume that $\epsilon^{\mathrm{d}}$ and $\epsilon^{\mathrm{s}}$ are independently and identically normally distributed with zero means and variances $\sigma_{\mathrm{d}}^{2}$ and $\sigma_{\mathrm{s}}^{2}$.

Substituting eqs. (2) and (3) into (4), taking (natural) logarithms and adding observational indices, we get the following model to be used for the estimation of the parameters:

$$
\begin{aligned}
\log Q_{i}^{\mathrm{d}}= & \delta_{0}+\delta_{1} F_{i}+\left(1+\delta_{2}\right) \log \left(1+M_{i}\right) \\
& +v_{i}\left(X_{i}^{\mathrm{c}}\right) \log \left(C_{i}-\gamma\right)+\epsilon_{i}^{\mathrm{d}} \\
\log Q_{i}^{\mathrm{s}}= & \beta_{0}+\log \left(1+M_{i}\right)+\beta_{1} \log \left(H_{i}\right) \\
& +\pi \epsilon \log \left(C_{i}-\gamma\right) \\
& +(1-\pi) \epsilon \log \left(W_{i}-C_{i}\right)+\epsilon_{i}^{\mathrm{s}}
\end{aligned}
$$

$\log Q_{i}=\min \left(\log Q_{i}^{\mathrm{d}}, \log Q_{i}^{\mathrm{s}}\right)$,

with $v_{i}\left(X_{i}^{\mathrm{c}}\right)=v_{0}+v_{\mathrm{a}} A_{i}+v_{\mathrm{s}} S_{i}+\delta_{f s} F s_{i}+$ $\delta_{r g} R g_{i}$.

Estimates of the model are obtained by the method of maximum likelihood. We refer to Appendix A to this paper for the derivation of the likelihood function $L(\bar{\theta})$ and the socalled regime probabilities. Numerical minimization of $-\log L$ with respect to the parameter vector $\bar{\theta}$ is performed by a comprehensive quasi-Newton algorithm (routine E04JBF from the NAG Fortran Library), which yields an estimate $\overline{\bar{\theta}}_{\mathrm{ML}}$ of $\bar{\theta}$. The asymptotic distribution of the maximum likelihood estimator $\bar{\theta}_{\mathrm{ML}}$ is multivariate normal with mean $\bar{\theta}$ and covariance matrix $\Sigma$.

A consistent estimate of $\Sigma$ is given by $\hat{\Sigma}$, where

$\hat{\Sigma}=\left(\frac{-\partial^{2} \log L}{\partial \bar{\theta} \partial \bar{\theta}^{\prime}}\right)^{-1} \quad$ evaluated at $\bar{\theta}=\hat{\bar{\theta}}_{\mathrm{ML}}$.

In this study use is made of Dutch survey data from the the Research Institute for Small and Medium-Sized Business (EIM) in Zoetermeer, The Netherlands. Samples from four different types of stores are used, viz., supermarkets and superettes, clothes stores, stationer's stores and furnishing stores. The surveying field force of the EIM defined (after consultation of the respective branch organisations) a 'type of stores', and gathered the data, in such a way that the samples obtained 
were rather homogeneous regarding assortment composition, extent of own production, service level and type of organisation. For the year of collection and more information on the data used, we refer to Appendix B to this paper. The same data were used in Van Dalen, Koerts and Thurik (1987).

\section{Results}

\subsection{Switching model}

Table 1 shows the parameter estimates of the switching model (5) for the four types of stores considered. The following conclusions can be drawn with respect to the demand parameters:

- $\hat{v}_{\mathrm{a}}$ (advertising effect): $\hat{v}_{\mathrm{a}}$ is significantly positive in all four cases. The effect of advertising on demand is the most striking for stationer's stores.

- $\hat{v}_{\mathrm{s}}$ (service effect): Demand is also significantly affected by service. Now the effect is highest for clothes stores, followed by furnishing stores.

- $\hat{\delta}_{2}$ (price effect): The effect of $(1+M)$ on demand is always significantly negative. The value of $\hat{\delta}_{2}$ is an estimate of the store price elasticity of demand: $\epsilon_{1+M}^{I}=(1+$ $M) / I \cdot \partial I / \partial(1+M)$. At first sight the estimates are somewhat high for the type of stores considered, but we used $1+M$ instead of a proper consumer store price index.

- $\hat{\delta}_{1}$ (assortment effect): The definition of the assortment variable $F$ depends on the type of stores (see Appendix B). Therefore, the values of $\hat{\delta}_{1}$ will be discussed separately. The results per type of stores are ${ }^{5}$

Supermarkets and superettes: $F$ is the share of fresh products in total value of annual

5 It should be noted that the estimation results (apart from the assortment effects themselves) do not change very much when one of the other assortment groups is used to construct F. sales. Stores with a high share of fresh products appear to realize a higher demand.

- Clothes stores: The share of children's clothing (as opposed to men's and women's) has a negative effect on demand. This effect, however, is not significant.

- Stationer's stores: Now $F$ is defined as the share of the kernel assortment, which consists of paper-ware, writing and drawingmaterials, machine supplies, etcetera. The following products are not part of this assortment group: typewriters, calculators, office furniture, books, periodicals, newspapers, etcetera. Stores with a high share of the kernel assortment appear to realize a higher demand, though not significantly.

- Furnishing stores: The share of furniture sales has a significantly negative effect on the level of demand. (Other assortment components in furnishing stores are floorcovering, carpets, and other furnishing, such as curtains.)

- $\hat{\delta}_{r g}$ (regional effect): Only for stationer's stores and furnishing stores this dummy variable was available. The value of $\hat{\delta}_{r g}$ appears to be significantly positive in both cases.

- $\hat{\delta}_{f s}$ (shopping centre effect): The sign of $\hat{\delta}_{f s}$ is as expected, except for stationer's stores, but no significant influence is found. The highest estimate is found for supermarkets.

- $\hat{v}_{0}$ (basic selling area effect): For furnishing stores $\hat{v}_{0}$ is significantly positive. Hence, there is a positive effect of selling space on demand (measured by $\hat{v}_{i}\left(X_{i}^{\mathrm{c}}\right)$ ), irrespective the level of advertising expenses, the level of service and the location. Also for supermarkets this effect is always positive. However, the basic effect $\hat{v}_{0}$ now does not significantly differ from zero. With respect to clothes stores and stationer's stores the effect of selling space on demand is only positive when at the same time, for example, advertising expenses, or service-level is high enough. However, inspecting the val- 
Table 1

Estimation results of switching model (5). ${ }^{\text {a }}$

\begin{tabular}{|c|c|c|c|c|}
\hline Type of stores & $\begin{array}{l}\text { Supermarkets } \\
\text { and superettes }\end{array}$ & $\begin{array}{l}\text { Clothes } \\
\text { stores }\end{array}$ & $\begin{array}{l}\text { Stationer's } \\
\text { stores }\end{array}$ & $\begin{array}{l}\text { Furnishing } \\
\text { stores }\end{array}$ \\
\hline \multicolumn{5}{|l|}{ Demand parameters } \\
\hline$v_{\mathrm{a}} \quad$ (advertising effect) & $\begin{array}{c}0.038 \\
(0.013)\end{array}$ & $\begin{array}{c}0.036 \\
(0.008)\end{array}$ & $\begin{array}{cc}\text { i } & 0.191 \\
& (0.060)\end{array}$ & $\begin{array}{c}0.038 \\
(0.005)\end{array}$ \\
\hline$v_{\mathrm{s}} \quad($ service effect $)$ & $\begin{array}{c}0.513 \\
(0.087)\end{array}$ & $\begin{array}{c}1.227 \\
(0.215)\end{array}$ & $\begin{array}{c}0.631 \\
(0.212)\end{array}$ & $\begin{array}{c}0.931 \\
(0.200)\end{array}$ \\
\hline$\delta_{2} \quad$ (price effect) & $\begin{array}{r}-3.411 \\
(1.033)\end{array}$ & $\begin{array}{r}-2.926 \\
(0.656)\end{array}$ & $\begin{array}{r}-3.103 \\
(0.758)\end{array}$ & $\begin{array}{c}-1.926 \\
(0.440)\end{array}$ \\
\hline$\delta_{1} \quad$ (assortment effect) & $\begin{array}{c}0.792 \\
(0.399)\end{array}$ & $\begin{array}{c}-0.656 \\
(0.440)^{*}\end{array}$ & $\begin{array}{c}0.339 \\
(0.307)^{*}\end{array}$ & $\begin{array}{c}-0.295 \\
(0.125)\end{array}$ \\
\hline$\delta_{r g} \quad$ (regional effect) & - & - & $\begin{array}{c}0.144 \\
(0.158)^{*}\end{array}$ & $\begin{array}{c}0.117 \\
(0.033)\end{array}$ \\
\hline$\delta_{f s} \quad$ (shopping centre effect) & $\begin{array}{c}0.073 \\
(0.092)^{*}\end{array}$ & $\begin{array}{c}0.069 \\
(0.099)^{*}\end{array}$ & $\begin{array}{l}-0.016 \\
(0.177)^{*}\end{array}$ & $\begin{array}{c}0.020 \\
(0.029)^{*}\end{array}$ \\
\hline$v_{0}$ & $\begin{array}{c}0.145 \\
(0.109)^{*}\end{array}$ & $\begin{array}{r}-0.350 \\
(0.172)\end{array}$ & $\begin{array}{c}-0.411 \\
(0.317)^{*}\end{array}$ & $\begin{array}{c}0.157 \\
(0.053)\end{array}$ \\
\hline$\delta_{0}$ & $\begin{array}{c}4.978 \\
(0.232)\end{array}$ & $\begin{array}{c}5.277 \\
(0.367)\end{array}$ & $\begin{array}{c}5.449 \\
(0.418)\end{array}$ & $\begin{array}{c}4.225 \\
(0.261)\end{array}$ \\
\hline \multicolumn{5}{|l|}{ Supply parameters } \\
\hline$\beta_{0}$ & $\begin{array}{c}0.188 \\
(0.504)\end{array}$ & $\begin{array}{c}0.466 \\
(0.461)^{*}\end{array}$ & $\begin{array}{c}0.539 \\
(0.862)^{*}\end{array}$ & $\begin{array}{c}0.424 \\
(0.431)^{*}\end{array}$ \\
\hline$\beta_{\mathrm{l}} \quad$ (occupancy costs effect) & $\begin{array}{c}0.850 \\
(0.107)\end{array}$ & $\begin{array}{c}0.639 \\
(0.088)\end{array}$ & $\begin{array}{c}0.702 \\
(0.177)\end{array}$ & $\begin{array}{c}0.615 \\
(0.091)\end{array}$ \\
\hline$\epsilon \quad$ (homogeneity parameter) & $\begin{array}{c}0.943 \\
(0.046)\end{array}$ & $\begin{array}{c}0.921 \\
(0.060)\end{array}$ & $\begin{array}{c}0.944 \\
(0.084)\end{array}$ & $\begin{array}{c}0.753 \\
(0.028)\end{array}$ \\
\hline$\pi \quad$ (distribution parameter) & $\begin{array}{c}0.669 \\
(0.055)\end{array}$ & $\begin{array}{c}0.652 \\
(0.042)\end{array}$ & $\begin{array}{c}0.455 \\
(0.079)\end{array}$ & $\begin{array}{c}0.807 \\
(0.048)\end{array}$ \\
\hline$\sigma_{\mathrm{d}}$ & $\begin{array}{c}0.191 \\
(0.023)\end{array}$ & $\begin{array}{c}0.314 \\
(0.036)\end{array}$ & $\begin{array}{c}0.378 \\
(0.047)\end{array}$ & $\begin{array}{c}0.305 \\
(0.022)\end{array}$ \\
\hline$\sigma_{\mathrm{s}}$ & $\begin{array}{c}0.253 \\
(0.022)\end{array}$ & $\begin{array}{c}0.242 \\
(0.021)\end{array}$ & $\begin{array}{c}0.381 \\
(0.037)\end{array}$ & $\begin{array}{c}0.159 \\
(0.034)\end{array}$ \\
\hline Number of observations & 208 & 189 & 138 & 176 \\
\hline $\log L$ (log likelihood) & 42.225 & 3.692 & -41.754 & 2.194 \\
\hline $\begin{array}{l}\text { pr. es } \quad \text { [average } \\
\text { pr (excess supply)] }\end{array}$ & 0.410 & 0.413 & 0.409 & 0.721 \\
\hline
\end{tabular}

${ }^{a}$ The estimate for the parameter $\gamma$ (selling area threshold) was consistently found to be zero. Therefore, it was left out of the table. An asterisk $\left(^{*}\right)$ is printed next to the standard error of $\hat{\theta}$ if $|\hat{\theta}|<1.645 \hat{\sigma}(\hat{\theta})$, that is, if $\hat{\theta}$ is not significantly different from zero at a $10 \%$ level of significance.

ues of $\hat{v}_{i}\left(X_{i}^{\mathrm{c}}\right)$ it appears that they are consistently positive in both samples.

The economic implications of the above results are not discussed in detail in this paper.
Our purpose is to demonstrate the importance of a proper estimation method.

With respect to the supply parameter estimates, we briefly conclude that they are all in accordance with our intuition. There 
appears to be a significantly positive effect of occupancy costs $\left(\hat{\beta}_{1}\right)$ on operating efficiency. The degree of homogeneity $(\hat{\boldsymbol{\epsilon}})$ is always somewhat smaller than one, though only significantly so for furnishing stores. This indicates that in the types of stores considered there are no economies of scale. The distribution parameter estimates indicate that in three out of the four types of stores selling area is relatively more important than remaining space in the determination of supply capacity $(\hat{\pi}>0.5) ; \hat{\pi}$ does not differ significantly from 0.5 for stationer's stores.

The squared correlation coefficients between actual and fitted values for model (5) are given in Appendix D. They all appear to be considerably high.

\subsection{Switching model vs. traditional regression approach}

In many studies dealing with the measurement of the effects of marketing instruments, a traditional regression approach is used to estimate the model parameters. Therefore, it is interesting to compare the estimation results of the switching model (5), with those of a single regression equation.

Let us suppose that relationship (2) (with $Q^{\text {d }}$ replaced by $Q$ ) would have been used to estimate the marketing mix effects. Taking logarithms, and adding a normal disturbance term and observational indices, we get the following equation:

$\log Q_{i}=\delta_{0}+\delta_{1} F_{i}+\left(1+\delta_{2}\right) \log \left(1+M_{i}\right)$

$$
+v_{i}\left(X_{i}^{\mathrm{c}}\right) \log \left(C_{i}-\gamma\right)+\epsilon_{i}
$$

with $v_{i}\left(X_{i}^{\mathrm{c}}\right)=v_{0}+v_{\mathrm{a}} A_{i}+v_{\mathrm{s}} S_{i}+\delta_{f s} F s_{i}+$ $\delta_{r g} R g_{i}$.

This equation can be estimated with the aid of the (complete) samples used in table 1 . However, once we have estimated the switching model (5), it is also possible to partition the samples a posteriori into 'excess supply' observations and 'excess demand' observations, and to estimate eq. (6) with the aid of these subsamples. As explained in the introduction we expect that the use of a single equation like (6) leads to biased estimation results: we expect that the marketing mix effects are underestimated compared with the results in table 1 . In addition, we believe that the most striking differences are found when eq. (6) is estimated using the excess demand subsamples.

Let us define observation $i$ to be in an excess supply regime if $\left|\hat{\epsilon}_{i}^{\mathrm{d}}\right|<\frac{4}{6}\left|\hat{\epsilon}_{i}^{\mathrm{s}}\right|$ (where $\hat{\epsilon}_{i}^{\mathrm{d}}$ and $\hat{\epsilon}_{i}^{\mathrm{s}}$ are the demand and supply residuals, respectively, of model (5)), and in an excess demand regime if $\left|\hat{\epsilon}_{i}^{\mathrm{d}}\right|>\frac{6}{4}\left|\hat{\epsilon}_{i}^{\mathrm{s}}\right|$.

If $\frac{4}{6}\left|\hat{\epsilon}_{i}^{\mathrm{s}}\right| \leq\left|\hat{\epsilon}_{i}^{\mathrm{d}}\right| \leq \frac{6}{4}\left|\hat{\epsilon}_{i}^{\mathrm{s}}\right|$ then no judgement is made with respect to the regime that applies to observation $i$. The scaling factors $\frac{4}{6}$ and $\frac{6}{4}$ are introduced to achieve a partitioning into 'real' excess supply observations, 'real' excess demand observations, and observations for which it is not very clear what regime applies. For example, according to this procedure the sample of supermarkets and superettes (208 observations) is partitioned into 61 'excess supply' observations, 96 'excess demand' observations, and 51 remaining observations (cf. also table 2). The values of the scaling factors are to some extent arbitrary.

Partitioning the four samples according to this procedure, and estimating eq. (6) on the excess demand observations, the complete samples, and the excess supply observations, respectively, we get the estimation results shown in the tables (see tables 2-5 for the results per type of stores; the demand parameter estimates of Table 1 are also printed in theses tables). ${ }^{6}$

\footnotetext{
${ }^{6}$ There are several other ways to partition the samples. One way is by using pr[excess supply $]_{i}$ (see Appendix A). A high value is an indication of an excess supply regime. Another way of partitioning is by means of the smallest of the fitted values $\left(\log Q_{i}^{\mathrm{d}}\right)$-circumflex $\left(=\log Q_{i}-\hat{\epsilon}_{i}^{\mathrm{d}}\right)$ and $\left(\log Q_{i}^{\mathrm{s}}\right)$-circumflex $\left(=\log Q_{i}-\hat{\epsilon}_{i}^{\mathrm{s}}\right)$. If $\left(\log Q_{i}^{\mathrm{d}}\right)$-circumflex $<\left(\log Q_{i}^{\mathrm{s}}\right)$ circumflex, then observation $i$ is said to be in an excess supply regime. Applying these alternative procedures, comparable results are obtained.
} 
Table 2

Estimation results of eq. (6) for supermarkets and superettes. ${ }^{a}$

\begin{tabular}{|c|c|c|c|c|c|}
\hline & & $\begin{array}{l}\text { Model (5) } \\
\text { complete } \\
\text { sample }\end{array}$ & $\begin{array}{l}\text { Eq. (6) } \\
\text { excess supply } \\
\text { observations }\end{array}$ & $\begin{array}{l}\text { Eq. (6) } \\
\text { complete } \\
\text { sample }\end{array}$ & $\begin{array}{l}\text { Eq. (6) } \\
\text { excess demand } \\
\text { observations }\end{array}$ \\
\hline \multicolumn{6}{|c|}{ Demand parameters } \\
\hline$v_{\mathrm{a}}$ & (advertising effect) & $\begin{array}{c}0.038 \\
(0.013)\end{array}$ & $\begin{array}{c}0.040 \\
(0.006)\end{array}$ & $\begin{array}{c}0.026 \\
(0.006)\end{array}$ & $\begin{array}{c}0.028 \\
(0.009)\end{array}$ \\
\hline$v_{\mathrm{s}}$ & (service effect) & $\begin{array}{c}0.513 \\
(0.087)\end{array}$ & $\begin{array}{c}0.499 \\
(0.046)\end{array}$ & $\begin{array}{c}0.506 \\
(0.066)\end{array}$ & $\begin{array}{c}0.511 \\
(0.112)\end{array}$ \\
\hline$\delta_{2}$ & (price effect) & $\begin{array}{r}-3.411 \\
(1.033)\end{array}$ & $\begin{array}{r}-3.850 \\
(0.566)\end{array}$ & $\begin{array}{r}-1.132 \\
(0.634)\end{array}$ & $\begin{array}{c}0.392 \\
(0.934) *\end{array}$ \\
\hline$\delta_{1}$ & (assortment effect) & $\begin{array}{c}0.792 \\
(0.399)\end{array}$ & $\begin{array}{c}0.749 \\
(0.169)\end{array}$ & $\begin{array}{c}0.498 \\
(0.205)\end{array}$ & $\begin{array}{l}0.299 \\
(0.319)^{*}\end{array}$ \\
\hline$\delta_{r g}$ & (regional effect) & - & - & - & - \\
\hline$\delta f_{s}$ & (shopping centre effect) & $\begin{array}{c}0.073 \\
(0.092)^{*}\end{array}$ & $\begin{array}{c}0.101 \\
(0.043)\end{array}$ & $\begin{array}{c}0.014 \\
(0.059)^{*}\end{array}$ & $\begin{array}{l}-0.036 \\
(0.085)^{*}\end{array}$ \\
\hline$v_{0}$ & & $\begin{array}{l}0.145 \\
(0.109)^{*}\end{array}$ & $\begin{array}{c}0.150 \\
(0.046)\end{array}$ & $\begin{array}{c}0.332 \\
(0.060)\end{array}$ & $\begin{array}{c}0.315 \\
(0.110)\end{array}$ \\
\hline$\delta_{0}$ & & $\begin{array}{c}4.978 \\
(0.232)\end{array}$ & $\begin{array}{c}5.041 \\
(0.111)\end{array}$ & $\begin{array}{c}4.266 \\
(0.133)\end{array}$ & $\begin{array}{c}3.976 \\
(0.204)\end{array}$ \\
\hline$\sigma_{\mathrm{d}}$ & & $\begin{array}{c}0.191 \\
(0.023)\end{array}$ & $\begin{array}{c}0.099 \\
(0.009)\end{array}$ & $\begin{array}{c}0.229 \\
(0.011)\end{array}$ & $\begin{array}{c}0.236 \\
(0.017)\end{array}$ \\
\hline \multicolumn{2}{|c|}{ number of observations } & 208 & 61 & 208 & 96 \\
\hline $\log L$ & (log likelihood) & 42.225 & 54.365 & 11.681 & 2.262 \\
\hline pr. es & $\begin{array}{l}\text { (average } \\
\text { pr (excess supply)) }\end{array}$ & 0.410 & [0.389] & - & - \\
\hline
\end{tabular}

a See the note to table 1 . The value in square brackets [0.389] is the fraction of excess supply observations in the union of excess supply and excess demand observations (i.e., $61 /(61+96))$.

We now also used the method of maximum likelihood to estimate the parameters, and the same optimization procedure was used as mentioned in section 3 . The squared correlation coefficients between actual and fitted values are given in Appendix D.

From these tables the following conclusions can be drawn:

(1) If we compare the switching model (5) (first column) with eq. (6) estimated on the complete samples (third column), we see that the (absolute values of the) parameter estimates of the marketing in- struments advertising, service level, price and assortment, for this latter equation have become considerably lower for all types of stores. For example, in the case of supermarkets and superettes (table 2) the advertising effect $\left(\hat{v}_{\mathrm{a}}\right)$ decreases from 0.038 and 0.026 ; the effect of service $\left(\hat{v}_{s}\right)$ decreases from 0.513 to 0.506 ; the price effect $\left(\hat{\delta}_{2}\right)$ decreases in absolute value from 3.411 to 1.132 ; and the assortment effect $\left(\hat{\delta}_{1}\right)$ decreases from 0.792 to 0.498 . The extent to which these parameter estimates have decreased in the tables 2-5 ranges from $22.2 \%$ to $80.1 \%$ for $\hat{v}_{\mathrm{a}}$; from 
Table 3

Estimation results of eq. (6) for clothes stores. ${ }^{a}$

\begin{tabular}{|c|c|c|c|c|c|}
\hline & & $\begin{array}{l}\text { Model (5) } \\
\text { complete } \\
\text { sample }\end{array}$ & $\begin{array}{l}\text { Eq. (6) } \\
\text { excess supply } \\
\text { observations }\end{array}$ & $\begin{array}{l}\text { Eq. (6) } \\
\text { complete } \\
\text { sample }\end{array}$ & $\begin{array}{l}\text { Eq. (6) } \\
\text { excess demand } \\
\text { observations }\end{array}$ \\
\hline \multicolumn{6}{|c|}{ Demand parameters } \\
\hline$v_{\mathrm{a}}$ & (advertising effect) & $\begin{array}{c}0.036 \\
(0.008)\end{array}$ & $\begin{array}{c}0.037 \\
(0.005)\end{array}$ & $\begin{array}{c}0.028 \\
(0.004)\end{array}$ & $\begin{array}{c}0.030 \\
(0.007)\end{array}$ \\
\hline$v_{\mathrm{s}}$ & (service effect) & $\begin{array}{c}1.227 \\
(0.215)\end{array}$ & $\begin{array}{c}1.369 \\
(0.165)\end{array}$ & $\begin{array}{c}0.841 \\
(0.122)\end{array}$ & $\begin{array}{c}0.831 \\
(0.172)\end{array}$ \\
\hline$\delta_{2}$ & (price effect) & $\begin{array}{r}-2.926 \\
(0.656)\end{array}$ & $\begin{array}{r}-3.418 \\
(0.379)\end{array}$ & $\begin{array}{r}-1.176 \\
(0.311)\end{array}$ & $\begin{array}{l}-0.094 \\
(0.423)^{*}\end{array}$ \\
\hline$\delta_{1}$ & (assortment effect) & $\begin{array}{l}-0.656 \\
(0.440)^{*}\end{array}$ & $\begin{array}{r}-0.815 \\
(0.334)\end{array}$ & $\begin{array}{r}-0.639 \\
(0.237)\end{array}$ & $\begin{array}{l}-0.452 \\
(0.306)^{*}\end{array}$ \\
\hline$\delta_{r g}$ & (regional effect) & - & - & - & - \\
\hline$\delta_{f s}$ & (shopping centre effect) & $\begin{array}{c}0.069 \\
(0.099)^{*}\end{array}$ & $\begin{array}{c}0.052 \\
(0.069)^{*}\end{array}$ & $\begin{array}{c}0.090 \\
(0.054)\end{array}$ & $\begin{array}{c}0.136 \\
(0.087)^{*}\end{array}$ \\
\hline$v_{0}$ & & $\begin{array}{r}-0.350 \\
(0.172)\end{array}$ & $\begin{array}{r}-0.331 \\
(0.107)\end{array}$ & $\begin{array}{l}0.003 \\
(0.093)^{*}\end{array}$ & $\begin{array}{c}0.005 \\
(0.158)^{*}\end{array}$ \\
\hline$\delta_{0}$ & & $\begin{array}{c}5.277 \\
(0.367)\end{array}$ & $\begin{array}{c}5.366 \\
(0.190)\end{array}$ & $\begin{array}{c}4.108 \\
(0.144)\end{array}$ & $\begin{array}{c}3.515 \\
(0.194)\end{array}$ \\
\hline$\sigma_{\mathrm{d}}$ & & $\begin{array}{c}0.314 \\
(0.036)\end{array}$ & $\begin{array}{c}0.183 \\
(0.019)\end{array}$ & $\begin{array}{c}0.288 \\
(0.015)\end{array}$ & $\begin{array}{c}0.261 \\
(0.019)\end{array}$ \\
\hline \multicolumn{2}{|c|}{ number of observations } & 189 & 48 & 189 & 98 \\
\hline $\log L$ & (log likelihood) & 3.692 & 13.451 & -32.681 & -7.566 \\
\hline pr. es & $\begin{array}{l}\text { (average } \\
\text { pr (excess supply) }\end{array}$ & 0.413 & {$[0.329]$} & - & - \\
\hline
\end{tabular}

a See the note to table 2 .

$1.4 \%$ to $45.6 \%$ for $\hat{v}_{s}$; from $43.0 \%$ to $66.8 \%$ for $\left|\hat{\delta}_{2}\right|$; and from $2.6 \%$ to $43.7 \%$ for $\left|\hat{\delta}_{1}\right|$.

(2) The results presented in the second and the fourth column give us an impression of how the results in the third column are reached. They seem to be a weighted average of the estimation results obtained with the excess supply and excess demand observations separately. For example, in table 2 the value of $\hat{\delta}_{2}$ in the third column $(-1.132)$ lies between the respective values in the second column and the fourth column ( -3.850 and 0.392). (There are some exceptions. For example, the value of $\hat{v}_{\mathrm{a}}$ in the third column of table 2 is lower than the respective values in the second column and the fourth column.) The parameter estimates of the marketing instruments in the second column (demand equation estimated on the excess supply observations) are very close to those in the first column (switching model).

(3) If we compare the values of the log-likelihoods in the first and the third column, it appears that the values for the switching model (5) are in excess of those for the single eq. (6). On the other hand, if we add the supply variables $\log \left(H_{i}\right)$ and $\log \left(W_{i}-C_{i}\right)$ to eq. (6), the values of the log-likelihoods for the single equation are 
Table 4

Estimation results of eq. (6) for stationer's stores. ${ }^{\text {a }}$

\begin{tabular}{|c|c|c|c|c|c|}
\hline & & $\begin{array}{l}\text { Model (5) } \\
\text { complete } \\
\text { sample }\end{array}$ & $\begin{array}{l}\text { Eq. (6) } \\
\text { excess supply } \\
\text { observations }\end{array}$ & $\begin{array}{l}\text { Eq. (6) } \\
\text { complete } \\
\text { sample }\end{array}$ & $\begin{array}{l}\text { Eq. (6) } \\
\text { excess demand } \\
\text { observations }\end{array}$ \\
\hline \multicolumn{6}{|c|}{ Demand parameters } \\
\hline$v_{a}$ & (advertising effect) & $\begin{array}{c}0.191 \\
(0.060)\end{array}$ & $\begin{array}{c}0.161 \\
(0.034)\end{array}$ & $\begin{array}{c}0.038 \\
(0.012)\end{array}$ & $\begin{array}{c}0.031 \\
(0.015)\end{array}$ \\
\hline$v_{s}$ & (service effect) & $\begin{array}{c}0.631 \\
(0.212)\end{array}$ & $\begin{array}{c}0.932 \\
(0.169)\end{array}$ & $\begin{array}{c}0.343 \\
(0.158)\end{array}$ & $\begin{array}{c}0.365 \\
(0.362)^{*}\end{array}$ \\
\hline$\delta_{2}$ & (price effect) & $\begin{array}{r}-3.103 \\
(0.758)\end{array}$ & $\begin{array}{c}-3.003 \\
(0.307)\end{array}$ & $\begin{array}{r}-1.426 \\
(0.499)\end{array}$ & $\begin{array}{c}1.539 * \\
(1.092)^{*}\end{array}$ \\
\hline$\delta_{1}$ & (assortment effect) & $\begin{array}{c}0.339 \\
(0.307)^{*}\end{array}$ & $\begin{array}{c}0.520 \\
(0.151)\end{array}$ & $\begin{array}{c}0.233 \\
(0.220)^{*}\end{array}$ & $\begin{array}{l}-0.458 \\
(0.427)^{*}\end{array}$ \\
\hline$\delta_{r, g}$ & (regional effect) & $\begin{array}{c}0.144 \\
(0.047)\end{array}$ & $\begin{array}{l}0.022 \\
(0.095)^{*}\end{array}$ & $\begin{array}{l}0.162 \\
(0.102)^{*}\end{array}$ & $\begin{array}{l}0.078 \\
(0.152)^{*}\end{array}$ \\
\hline$\delta_{/ s}$ & (shopping centre effect) & $\begin{array}{l}-0.016 \\
(0.177)^{*}\end{array}$ & $\begin{array}{l}-0.087 \\
(0.080)^{*}\end{array}$ & $\begin{array}{l}0.038 \\
(0.104)^{*}\end{array}$ & $\begin{array}{c}0.201 \\
(0.164)^{*}\end{array}$ \\
\hline$v_{0}$ & & $\begin{array}{c}-0.411 \\
(0.317)\end{array}$ & $\begin{array}{r}-0.449 \\
(0.139)\end{array}$ & $\begin{array}{c}0.216 \\
(0.149)^{*}\end{array}$ & $\begin{array}{c}0.260 \\
(0.304)^{*}\end{array}$ \\
\hline$\delta_{0}$ & & $\begin{array}{c}5.449 \\
(0.418)\end{array}$ & $\begin{array}{c}5.253 \\
(0.117)\end{array}$ & $\begin{array}{c}4.399 \\
(0.182)\end{array}$ & $\begin{array}{c}3.417 \\
(0.385)\end{array}$ \\
\hline$\sigma_{\mathrm{d}}$ & & $\begin{array}{c}0.378 \\
(0.047)\end{array}$ & $\begin{array}{c}0.177 \\
(0.019)\end{array}$ & $\begin{array}{c}0.424 \\
(0.026)\end{array}$ & $\begin{array}{c}0.418 \\
(0.038)\end{array}$ \\
\hline \multicolumn{2}{|c|}{ number of observations } & 138 & 44 & 138 & 62 \\
\hline $\log L$ & (log likelihood) & -41.754 & 13.717 & -77.394 & -33.844 \\
\hline pr.es & $\begin{array}{l}\text { (average } \\
\text { pr [excess supply]) }\end{array}$ & 0.409 & [0.415] & - & - \\
\hline
\end{tabular}

See note to table 2 .

in excess of those for the switching model (5). (The estimation results of this single equation are given in Appendix C.) However, we should be very careful in drawing conclusions with respect to the adequacy of a model, only by comparing log-likelihoods: firstly, it is questionable whether likelihoods of non-nested models can be compared. Secondly, although we propose to use a switching model to get unbiased estimates, this does not imply that a switching model should always produce a better fit. For, as Durbin argues in a discussion on a paper by Coen, Gomme and Kendall: 'As far as short-term eco- nomic forecasting is concerned, my feeling is that it is not clear at present whether one does better to fit economic models based on postulated relationship between the variables, or to use statistical forecasting of a frankly ad hoc character' (Coen, Gomme and Kendall (1969: 153)). 'Ihirdly, inspecting the tables 2-5, we see that the log-likelihoods of the demand equation estimated on the excess supply observations (second column), are higher than those of the expanded single equation estimated on the complete samples (Appendix C), whereas the number of parameters of the demand equation is 
Table 5

Estimation results of eq. (6) for furnishing stores. ${ }^{\text {a }}$

\begin{tabular}{|c|c|c|c|c|c|}
\hline & & $\begin{array}{l}\text { Model (5) } \\
\text { complete } \\
\text { ample }\end{array}$ & $\begin{array}{l}\text { Eq. (6) } \\
\text { excess supply } \\
\text { observations }\end{array}$ & $\begin{array}{l}\text { Eq. (6) } \\
\text { complete } \\
\text { sample }\end{array}$ & $\begin{array}{l}\text { Eq. (6) } \\
\text { excess demand } \\
\text { observations }\end{array}$ \\
\hline \multicolumn{6}{|c|}{ Demand parameters } \\
\hline$v_{a}$ & (advertising effect) & $\begin{array}{c}0.038 \\
(0.005)\end{array}$ & $\begin{array}{c}0.038 \\
(0.004)\end{array}$ & $\begin{array}{c}0.020 \\
(0.002)\end{array}$ & $\begin{array}{c}0.008 \\
(0.004)\end{array}$ \\
\hline$v_{s}$ & (service effect) & $\begin{array}{c}0.931 \\
(0.200)\end{array}$ & $\begin{array}{c}1.189 \\
(0.180)\end{array}$ & $\begin{array}{c}0.732 \\
(0.149)\end{array}$ & $\begin{array}{c}0.356 \\
(0.241)^{*}\end{array}$ \\
\hline$\delta_{2}$ & (price effect) & $\begin{array}{r}-1.926 \\
(0.440)\end{array}$ & $\begin{array}{r}-1.789 \\
(0.351)\end{array}$ & $\begin{array}{r}-1.098 \\
(0.334)\end{array}$ & $\begin{array}{c}1.252 \\
(0.683)\end{array}$ \\
\hline$\delta_{1}$ & (assortment effect) & $\begin{array}{r}-0.295 \\
(0.125)\end{array}$ & $\begin{array}{r}-0.290 \\
(0.087)\end{array}$ & $\begin{array}{c}-0.166 \\
(0.105)^{*}\end{array}$ & $\begin{array}{l}0.173 \\
(0.204)^{*}\end{array}$ \\
\hline$\delta_{r g}$ & (regional effect) & $\begin{array}{c}0.117 \\
(0.033)\end{array}$ & $\begin{array}{c}0.105 \\
(0.021)\end{array}$ & $\begin{array}{c}0.099 \\
(0.024)\end{array}$ & $\begin{array}{c}0.047 \\
(0.052)^{*}\end{array}$ \\
\hline$\delta_{f s}$ & (shopping centre effect) & $\begin{array}{c}0.020 \\
(0.029)^{*}\end{array}$ & $\begin{array}{c}0.016 \\
(0.019)^{*}\end{array}$ & $\begin{array}{c}0.040 \\
(0.023)\end{array}$ & $\begin{array}{c}0.099 \\
(0.046)\end{array}$ \\
\hline$v_{0}$ & & $\begin{array}{c}0.157 \\
(0.053)\end{array}$ & $\begin{array}{c}0.199 \\
(0.036)\end{array}$ & $\begin{array}{c}0.293 \\
(0.039)\end{array}$ & $\begin{array}{c}0.370 \\
(0.100)\end{array}$ \\
\hline$\delta_{0}$ & & $\begin{array}{c}4.225 \\
(0.261)\end{array}$ & $\begin{array}{c}3.921 \\
(0.200)\end{array}$ & $\begin{array}{c}3.624 \\
(0.188)\end{array}$ & $\begin{array}{c}2.614 \\
(0.363)\end{array}$ \\
\hline$\sigma_{\mathrm{d}}$ & & $\begin{array}{c}0.305 \\
(0.022)\end{array}$ & $\begin{array}{c}0.181 \\
(0.013)\end{array}$ & $\begin{array}{c}0.287 \\
(0.015)\end{array}$ & $\begin{array}{c}0.277 \\
(0.031)\end{array}$ \\
\hline \multicolumn{2}{|c|}{ number of observations } & 176 & 98 & 176 & 41 \\
\hline $\log L$ & (log likelihood) & 2.194 & 28.704 & -29.812 & -5.516 \\
\hline pr. es & $\begin{array}{l}\text { (average } \\
\text { pr (excess supply) }\end{array}$ & 0.721 & {$[0.705]$} & - & - \\
\hline
\end{tabular}

\footnotetext{
a See note to table 2 .
}

lower. This is in accordance with our idea that different economic regimes are present, and that the estimation of a single equation on the complete samples results in a 'mongrel'.

These results support our hypothesis: due to the presence of both excess supply and excess demand observations in the complete samples, the marketing mix effects are underestimated when a single equation like (6) is used. The parameter estimates are, in fact, a weighted average of the estimation results obtained with the excess supply observations and the excess demand observations separately. The application of a switching model, on the other hand, takes into account that different economic regimes are possible.

\section{Conclusions and further research}

This study shows that when analyzing the effects of marketing instruments on sales, it is important to realize that a store may operate under different economic regimes. When sales are supply-determined, i.e., when demand exceeds store capacity, a slight change in the level of, say, advertising expenses probably will not have a large impact on the value of annual sales. The opposite holds true in case 
of an excess supply situation: store capacity now is large enough to meet demand, and a change in advertising expenses almost surely will change sales level.

In this paper we presented a so-called switching model to analyse the influence of marketing variables on the value of annual store sales. The model was estimated for four largely differing types of stores in the retail trade.

The results of this analysis were compared with those of a traditional regression model explaining the sales level. The main conclusions of our study are

- The use of a single regression equation leads to considerable underestimation of the effects of marketing instruments on annual store sales.

- A switching model seems to be a promising instrument for analyzing these effects properly.

Some of the results of the switching model are

- The amount of advertising expenses has a significantly positive effect on the level of demand.

- The service (measured by the volume of labour per unit of floorspace) also has a significantly positive influence on demand.

- When price level is approximated by sales value over purchasing value of annual sales (i.e., $Q / I$ ), the effect on demand turns out to be significantly negative for all types of stores considered. For furnishing stores the effect is somewhat lower than for the other types of stores.

At the end of this study some caveats should be stressed and some notes on further research scem appropriate.

Firstly, in further research more attention should be paid to the behavioral characteristics of switching models. For example, does the estimated average probability of excess supply approximate the sample distribution of stores that really are in an excess supply regime? And, how robust are the parameter estimates when one of the model equations is extended by adding variables? In the near future we hope to analyse some of these aspects of switching models, by means of a data set that contains prior information with respect to the regime under which a store operates (excess supply or excess demand).

Secondly, although we stressed the importance of using a proper model for the analysis of marketing mix effects, which resulted in this study into a switching model, we do not claim that the demand and supply equations used in the model cannot be improved. For example, also in our study only a number of the elements mentioned by Parsons and Schultz (1976: 39-40) are included into the demand equation.

Thirdly, the use of the price index, $1+M$, has some drawbacks. For example, purchasing price differences that are due to differences in purchasing quantities, might very well lead to differences in the value of $1+M$ despite the fact that selling prices are about equal. In addition, the assortment composition is not taken into account in the construction of the store price index.

Despite these facts we think that this study serves as a contribution to the measurement of the effects of marketing instruments at the individual store level. The method deserves further testing outside the retail trade.

\section{Appendix A: Likelihood}

Let $f\left(\epsilon_{i}^{\mathrm{d}}, \epsilon_{i}^{\mathrm{s}}\right)$ be the joint density of $\epsilon_{i}^{\mathrm{d}}$ and $\epsilon_{i}^{\mathrm{s}}$ in model (5), and $g\left(\log Q_{i}^{\mathrm{d}}, \log Q_{i}^{\mathrm{s}}\right)$ the joint density of $\log Q_{i}^{\mathrm{d}}$ and $\log Q_{i}^{\mathrm{s}}$ derived from it. Then it follows that (see for example Maddala (1983: 297)) the (unconditional) density of $\log Q_{i}$ is

$$
\begin{aligned}
& h\left(\log Q_{i}\right) \\
& \quad=h^{e s}\left(\log Q_{i}\right)+h^{e \mathrm{~d}}\left(\log Q_{i}\right),
\end{aligned}
$$


where

$$
\begin{aligned}
& h^{e s}\left(\log Q_{i}\right) \\
& \quad=\int_{\log Q_{i}}^{\infty} g\left(\log Q_{i}, \log Q_{i}^{\mathrm{s}}\right) \mathrm{d} \log Q_{i}^{\mathrm{s}}
\end{aligned}
$$

and

$$
\begin{aligned}
& h^{\text {ed }}\left(\log Q_{i}\right) \\
& \quad=\int_{\log Q_{i}}^{\infty} g\left(\log Q_{i}^{\mathrm{d}}, \log Q_{i}\right) \mathrm{d} \log Q_{i}^{\mathrm{d}} .
\end{aligned}
$$

In our situation where $\epsilon_{i}^{\mathrm{d}}$ and $\epsilon_{i}^{s}$ are independently and identically normally distributed, $h^{e s}\left(\log Q_{i}\right)$ and $h^{e \mathrm{~d}}\left(\log A_{i}\right)$ can be written as $h^{r s}\left(\log Q_{i}\right)$

$$
\begin{aligned}
= & \mathrm{n}\left(\log Q_{i}-\log Q_{i}^{\mathrm{d}}\left(C_{i}, X_{i}^{\mathrm{d}}\right) ; \sigma_{\mathrm{d}}\right) \\
& \times\left(1-\mathrm{N}\left(\frac{\log Q_{i}-\log Q_{i}^{\mathrm{s}}\left(C_{i}, W_{i}, W_{i}^{\mathrm{s}}\right)}{\sigma_{\mathrm{s}}}\right)\right)
\end{aligned}
$$

and

$$
\begin{aligned}
& h^{e \mathrm{~d}}\left(\log Q_{i}\right) \\
&=\mathrm{n}\left(\log Q_{i}-\log Q_{i}^{\mathrm{s}}\left(C_{i}, W_{i}, X_{i}^{\mathrm{s}}\right) ; \sigma_{\mathrm{s}}\right) \\
& \quad \times\left(1-\mathrm{N}\left(\frac{\log Q_{i}-\log Q_{i}^{\mathrm{d}}\left(C_{i}, X_{i}^{\mathrm{d}}\right)}{\sigma_{\mathrm{d}}}\right)\right),
\end{aligned}
$$

respectively, where

$\mathrm{n}(. ; \sigma)=$ normal density function with zero mean and variance $\sigma^{2}$,

$\mathrm{N}() \quad=$. cumulative standardized normal distribution function.

The likelihood function is

$$
\begin{aligned}
L & =\prod_{i} h\left(\log Q_{i}\right) \\
& =\prod_{i}\left\{h^{e s}\left(\log Q_{i}\right)+h^{e \mathrm{~d}}\left(\log Q_{i}\right)\right\} .
\end{aligned}
$$

The regime probabilities according to Kiefer (1980) can be derived as (cf., Kooiman, Van Dijk and Thurik (1985)):

$\operatorname{pr}[\text { excess supply }]_{i}$ :

$$
\begin{aligned}
& =\operatorname{pr}\left[\log Q_{i}^{\mathrm{d}} \leq \log Q_{i}^{\mathrm{s}} \mid \log Q_{i}\right] \\
& =\frac{h^{e s}\left(\log Q_{i}\right)}{h\left(\log Q_{i}\right)}
\end{aligned}
$$

and

$$
\begin{aligned}
& \operatorname{pr}[\text { excess demand }]_{i}: \\
& \quad=\operatorname{pr}\left[\log Q_{i}^{\mathrm{d}} \geq \log Q_{i}^{\mathrm{s}} \mid \log Q_{i}\right] \\
& \quad=\frac{h^{\text {ed }}\left(\log Q_{i}\right)}{h\left(\log Q_{i}\right)} .
\end{aligned}
$$

The likelihood function (A6) tends to go to infinity for certain parameter values. Maddala (1983) and Kooiman et al. deal quite extensively with this matter. This problem is suppressed by restricting the average pr(excess supply) to the interval $\left[\alpha_{0}, \alpha_{1}\right]$, where $0<\alpha_{0}<\alpha_{1}<1$. (In this study $\alpha_{0}=0.15$ and $\alpha_{1}=0.85$ for all types of stores.)

\section{Appendix B: Data}

In this appendix we give a description of the data set we used in this study. As mentioned in the paper, these (Dutch) data were gathered by the surveying field force of the Research Institute for Small and MediumSized Business (EIM) in Zoetermeer, The Netherlands. Cross-section samples from four different types of stores were used, viz., supermarkets and superettes (1979), clothes stores (1979), stationer's stores (1980) and furnishing stores (1981).

The surveying field force of the EIM (after consultation of the respective branch organisations) defined for each type of stores several assortment components. On the basis of these components we made a partitioning into three assortment groups (see table B1). We defined the share of the first assortment group in total sales value as the variable $F$ used in the study. In the tables B2-B5 the mean, standard deviation, the minimum and the maximum of the variables used arc given. In thesc tables total floorspace $(W)$ and selling area $(C)$ are measured in $100 \mathrm{~m}^{2}$; annual sales $(Q)$, purchasing value $(I)$ and advertising expenditures $(A)$ are measured in 10.000 Dutch guilders (of the years of collection); the vari- 
Table B1

Definition of assortment groups.

Supermarkets/ Ass. group 1. fresh products: meat and meatproducts, vegetables, bread, etcetera.

superettes:

2. non-foods

3. other foods (except fresh products)

Clothes stores:

Ass. group 1. children's wear

2. men's wear

3. women's wear

Stationer's stores:

Ass. group 1. kernel assortment: paper-ware, writing and drawing-materials, machine supplies, etc.

2. complementary assortment: typewriters, calculators, office furniture, etc.

Furnishing stores:

3. books, periodicals, newspapers, printing-works, copy service, etc.

Ass. group 1. furniture

2. floor-covering, carpets

3. other furnishing, like curtains

able $H$ is measured as the annual occupancy costs per square metre of total floorspace; the level of services $(S)$ is measured as the aver-

Table B2

Supermarkets and superettes (208 observations)

\begin{tabular}{lrrrr}
\hline & Mean & St. dev. & $\begin{array}{l}\text { Minimum } \\
\text { value }\end{array}$ & $\begin{array}{l}\text { Maximum } \\
\text { value }\end{array}$ \\
\hline$W$ & 4.143 & 2.527 & 0.730 & 16.900 \\
$C$ & 2.871 & 1.873 & 0.380 & 10.000 \\
$Q$ & 218.751 & 147.997 & 47.504 & 749.588 \\
$I$ & 174.684 & 116.918 & 37.727 & 595.767 \\
$H$ & 172.682 & 51.920 & 48.396 & 319.361 \\
$A$ & 2.826 & 2.368 & 0.029 & 10.829 \\
$S$ & 0.900 & 0.272 & 0.324 & 1.899 \\
$1+M$ & 1.247 & 0.035 & 1.151 & 1.338 \\
$F_{1}(=F)$ & 0.399 & 0.093 & 0.050 & 0.630 \\
$F_{2}$ & 0.084 & 0.031 & 0.010 & 0.200 \\
$F_{2}$ & 0.517 & 0.088 & 0.320 & 0.810 \\
$F_{3}$ & 0.077 & 0.267 & 0.000 & 1.000 \\
\hline
\end{tabular}

Table B3

Clothes stores (189 observations).

\begin{tabular}{lrrcc}
\hline & Mean & St. dev. & $\begin{array}{l}\text { Minimum } \\
\text { value }\end{array}$ & $\begin{array}{l}\text { Maximum } \\
\text { value }\end{array}$ \\
\hline$W$ & 3.714 & 2.585 & 0.650 & 20.400 \\
$C$ & 2.720 & 1.834 & 0.500 & 13.600 \\
$Q$ & 106.596 & 67.757 & 27.843 & 495.182 \\
$I$ & 67.868 & 41.228 & 17.867 & 308.872 \\
$H$ & 223.504 & 114.045 & 59.407 & 980.330 \\
$A$ & 3.219 & 3.307 & 0.010 & 24.341 \\
$S$ & 0.628 & 0.231 & 0.192 & 1.449 \\
$I+M$ & 1.565 & 0.116 & 1.307 & 2.061 \\
$F_{1}(=F)$ & 0.069 & 0.092 & 0.000 & 0.490 \\
$F_{2}$ & 0.431 & 0.432 & 0.000 & 1.000 \\
$F_{3}$ & 0.499 & 0.444 & 0.000 & 1.000 \\
$F S$ & 0.772 & 0.420 & 0.000 & 1.000 \\
\hline
\end{tabular}

Table B4

Stationer's stores (138 observations).

\begin{tabular}{lrrrr}
\hline & \multicolumn{1}{c}{ Mean } & St. dev. & $\begin{array}{l}\text { Minimum } \\
\text { value }\end{array}$ & $\begin{array}{l}\text { Maximum } \\
\text { value }\end{array}$ \\
\hline$W$ & 3.407 & 2.799 & 0.520 & 16.180 \\
$C$ & 1.843 & 1.452 & 0.250 & 9.000 \\
$Q$ & 117.929 & 95.801 & 22.952 & 611.604 \\
$I$ & 78.552 & 63.775 & 12.351 & 400.095 \\
$H$ & 190.074 & 77.067 & 57.001 & 444.612 \\
$A$ & 1.703 & 2.139 & 0.037 & 17.204 \\
$S$ & 0.845 & 0.385 & 0.273 & 2.692 \\
$1+M$ & 1.516 & 0.140 & 1.293 & 1.986 \\
$F_{1}(=F)$ & 0.475 & 0.206 & 0.170 & 1.000 \\
$F_{2}$ & 0.159 & 0.207 & 0.000 & 0.740 \\
$F_{3}$ & 0.367 & 0.285 & 0.000 & 0.780 \\
$F s$ & 0.623 & 0.486 & 0.000 & 1.000 \\
$R g$ & 0.413 & 0.494 & 0.000 & 1.000 \\
\hline
\end{tabular}

Table B5

Furnishing stores (176 observations).

\begin{tabular}{lrrrr}
\hline & \multicolumn{1}{c}{ Mean } & St. dev & $\begin{array}{l}\text { Minimum } \\
\text { value }\end{array}$ & $\begin{array}{l}\text { Maximum } \\
\text { value }\end{array}$ \\
\hline$W$ & 12.740 & 10.396 & 1.200 & 47.500 \\
$C$ & 9.339 & 7.835 & 0.500 & 34.000 \\
$Q$ & 121.483 & 85.615 & 18.939 & 420.074 \\
$I$ & 73.889 & 53.483 & 10.119 & 277.262 \\
$H$ & 100.137 & 44.957 & 22.406 & 256.242 \\
$A$ & 4.173 & 4.631 & 0.112 & 26.565 \\
$S$ & 0.251 & 0.172 & 0.034 & 0.808 \\
$1+M$ & 1.661 & 0.121 & 1.389 & 2.165 \\
$F_{1}(=F)$ & 0.481 & 0.287 & 0.000 & 1.000 \\
$F_{2}$ & 0.228 & 0.175 & 0.000 & 1.000 \\
$F_{3}$ & 0.291 & 0.200 & 0.000 & 1.000 \\
$F S$ & 0.511 & 0.501 & 0.000 & 1.000 \\
$R g$ & 0.392 & 0.490 & 0.000 & 1.000 \\
\hline
\end{tabular}


Table C1

Estimation results of eq. (C1). ${ }^{a}$

\begin{tabular}{|c|c|c|c|c|c|}
\hline \multicolumn{2}{|c|}{ Type of stores } & $\begin{array}{l}\text { Supermarkets } \\
\text { and superettes }\end{array}$ & $\begin{array}{l}\text { Clothes } \\
\text { stores }\end{array}$ & $\begin{array}{l}\text { Stationer's } \\
\text { stores }\end{array}$ & $\begin{array}{l}\text { Fumishing } \\
\text { stores }\end{array}$ \\
\hline \multicolumn{6}{|c|}{ Demand parameters } \\
\hline$v_{\mathrm{a}}$ & (advertising effect) & $\begin{array}{c}0.015 \\
(0.005)\end{array}$ & $\begin{array}{c}0.015 \\
(0.004)\end{array}$ & $\begin{array}{c}0.027 \\
(0.009)\end{array}$ & $\begin{array}{c}0.015 \\
(0.002)\end{array}$ \\
\hline$v_{\mathrm{s}}$ & (service effect) & $\begin{array}{c}0.397 \\
(0.059)\end{array}$ & $\begin{array}{c}0.776 \\
(0.098)\end{array}$ & $\begin{array}{c}0.238 \\
(0.120)\end{array}$ & $\begin{array}{c}0.624 \\
(0.130)\end{array}$ \\
\hline$\delta_{2}$ & (price effect) & $\begin{array}{r}-1.143 \\
(0.521)\end{array}$ & $\begin{array}{r}-1.644 \\
(0.249)\end{array}$ & $\begin{array}{r}-1.860 \\
(0.378)\end{array}$ & $\begin{array}{r}-1.450 \\
(0.280)\end{array}$ \\
\hline$\delta_{1}$ & (assortment effect) & $\begin{array}{c}0.405 \\
(0.169)\end{array}$ & $\begin{array}{c}-0.109 \\
(0.193)^{*}\end{array}$ & $\begin{array}{c}-0.095 \\
(0.170)^{*}\end{array}$ & $\begin{array}{r}-0.222 \\
(0.086)\end{array}$ \\
\hline$\delta_{r g}$ & (regional effect) & - & - & $\begin{array}{c}0.047^{*} \\
(0.078)^{*}\end{array}$ & $\begin{array}{c}0.071 \\
(0.020)\end{array}$ \\
\hline$\delta_{f s}$ & (shopping centre effect) & $\begin{array}{c}0.017 \\
(0.049)^{*}\end{array}$ & $\begin{array}{c}-0.037 \\
(0.044)^{*}\end{array}$ & $\begin{array}{c}-0.012 \\
(0.078)^{*}\end{array}$ & $\begin{array}{c}0.007 \\
(0.019)^{*}\end{array}$ \\
\hline$\delta_{0}$ & & $\begin{array}{c}1.928 \\
(0.286)\end{array}$ & $\begin{array}{c}2.436 \\
(0.281)\end{array}$ & $\begin{array}{c}2.279 \\
(0.425)\end{array}$ & $\begin{array}{c}1.844 \\
(0.270)\end{array}$ \\
\hline \multicolumn{6}{|c|}{ Supply parameters } \\
\hline$\beta_{1}$ & (occupancy costs effect) & $\begin{array}{c}0.501 \\
(0.055)\end{array}$ & $\begin{array}{c}0.380 \\
(0.050)\end{array}$ & $\begin{array}{c}0.490 \\
(0.080)\end{array}$ & $\begin{array}{c}0.419 \\
(0.053)\end{array}$ \\
\hline$\epsilon$ & (homogeneity parameter) & $\begin{array}{c}0.467 \\
(0.051)\end{array}$ & $\begin{array}{c}0.312 \\
(0.082)\end{array}$ & $\begin{array}{c}0.528 \\
(0.118)\end{array}$ & $\begin{array}{c}0.542 \\
(0.041)\end{array}$ \\
\hline$\pi$ & (distribution parameter) & $\begin{array}{c}0.520 \\
(0.078)\end{array}$ & $\begin{array}{c}0.239 \\
(0.208)\end{array}$ & $\begin{array}{c}0.209 \\
(0.181)^{*}\end{array}$ & $\begin{array}{c}0.650 \\
(0.053)\end{array}$ \\
\hline$\sigma$ & & $\begin{array}{c}0.187 \\
(0.009)\end{array}$ & $\begin{array}{c}0.226 \\
(0.012)\end{array}$ & $\begin{array}{c}0.318 \\
(0.019)\end{array}$ & $\begin{array}{c}0.235 \\
(0.013)\end{array}$ \\
\hline numb & bservations & 208 & 189 & 138 & 176 \\
\hline $\log L$ & (log likelihood) & 53.058 & 13.089 & -37.571 & 5.152 \\
\hline
\end{tabular}

See note to table 1 .

Table D1

Squared correlation coefficients between actual values $(\log Q)$ and fitted values $\left((\log Q)-{\text { circumflex }){ }^{\text {a }}}\right.$

\begin{tabular}{|c|c|c|c|c|c|}
\hline $\begin{array}{l}\text { Type } \\
\text { of } \\
\text { stores }\end{array}$ & $\begin{array}{l}\text { Eq. (6) } \\
\text { excess supply } \\
\text { observations }\end{array}$ & $\begin{array}{l}\text { Eq. (C1) } \\
\text { complete } \\
\text { sample }\end{array}$ & $\begin{array}{l}\text { Model (5) } \\
\text { complete } \\
\text { sample }\end{array}$ & $\begin{array}{l}\text { Eq. (6) } \\
\text { complete } \\
\text { sample }\end{array}$ & $\begin{array}{l}\text { Eq. (6) } \\
\text { excess demand } \\
\text { observations }\end{array}$ \\
\hline & $\rho^{2}$ & $\rho^{2}$ & $\rho^{2} / \rho_{2}^{2} / \rho_{3}^{2}$ & $\rho^{2}$ & $\rho^{2}$ \\
\hline $\begin{array}{l}\text { Supcrmarkcts } \\
\text { superettes }\end{array}$ & 0.958 & 0.927 & $0.934 / 0.911 / 0.912$ & 0.892 & 0.891 \\
\hline Clothes stores & 0.857 & 0.823 & $0.835 / 0.781 / 0.784$ & 0.712 & 0.769 \\
\hline Stationer's stores & 0.747 & 0.755 & $0.805 / 0.710 / 0.710$ & 0.564 & 0.679 \\
\hline Furnishing stores & 0.869 & 0.871 & $0.960 / 0.843 / 0.851$ & 0.808 & 0.870 \\
\hline
\end{tabular}

a The fitted values of model (5) can be defined in several ways: $\rho_{1}^{2}$ corresponds with the definition $\left(\log Q_{i}\right)$-circumflex $=\log Q_{i}-\hat{\epsilon}_{i}^{*}$, where $\hat{\epsilon}_{i}^{*}$ is either $\hat{\epsilon}_{i}^{\mathrm{d}}$ or $\hat{\epsilon}_{i}^{\mathrm{s}}$, depending on which one has the smallest absolute value; $\rho_{2}^{2}$ corresponds with (log $\left.Q_{i}^{\mathrm{d}}\right)$-circumflex $=$ $\min \left(\log Q_{i}-\hat{\epsilon}_{i}^{\mathrm{d}}, \log Q_{i}-\hat{\epsilon}_{i}^{\mathrm{s}}\right)=\min \left(\left(\log Q_{i}^{\mathrm{d}}\right)\right.$-circumflex, $\left(\log Q_{i}^{\mathrm{s}}\right)$-circumflex); $\rho_{3}^{2}$ corresponds with $\left(\log Q_{i}\right)$-circumflex $=\log Q_{i}$ $-\hat{\epsilon}_{i}^{* *}$, where $\hat{\epsilon}_{i}^{* *}$ is either $\hat{\epsilon}_{i}^{\mathrm{d}}$ or $\hat{\epsilon}_{i}^{\mathrm{s}}$, depending on whether pr[excess supply] $]_{i}$ (see Appendix A) is larger or smaller than 0.5 , respectively. 
age number of weekly working hours per square metre of total floorspace; and the assortment variables $F_{i}$ are measured as the value of annual sales of assortment group $i$ (table B1), divided by total value of annual sales $(i=1,2,3)$.

\section{Appendix C: Alternative single equation}

In this appendix we present the parameter estimates of a single equation that results when the supply variables $\log \left(H_{i}\right)$ and $\log \left(W_{i}\right.$ $-C_{i}$ ) are added to eq. (6) in the following way:

$$
\begin{aligned}
\log Q_{i}= & \delta_{0}+\delta_{1} F_{i}+\beta_{1} \log \left(H_{i}\right) \\
& +\left(1+\delta_{2}\right) \log \left(1+M_{i}\right) \\
& +\left(\pi \epsilon+\tilde{v}_{i}\left(X_{i}^{\mathrm{c}}\right)\right) \log \left(C_{i}-\gamma\right) \\
& +(1-\pi) \epsilon \log \left(W_{i}-C_{i}\right)+\epsilon_{i},
\end{aligned}
$$

with $\tilde{v}_{i}\left(X_{i}^{\mathrm{c}}\right)=v_{\mathrm{a}} A_{i}+v_{\mathrm{s}} S_{i}+\delta_{f s} F s_{i}+\delta_{r g} R g_{i}$. The estimation results are given in table $\mathrm{C} 1$.

\section{Appendix D: Squared correlation coefficients}

In table D1 we present the squared correlation coefficients between the actual values $(\log Q)$ and the fitted values $((\log Q)$-circumflex) of all models estimated in this paper.

\section{References}

Bass, M. and L.J. Parsons, 1969. Simultaneous-equation regression analysis of sales and advertising. Applied Econonics 1 (May), 103-124.

Coen, P.J., E.D. Gomme and M.G. Kendall, 1969. Lagged relationships in economic forecasting. Proceedings of the Royal Statistical Society Meeting, January 1969, 133-163.

Curhan, R.C., 1974. The effects of merchandising and tem- porary promotional activities on the sales of fresh fruits and vegetables in supermarkets. Journal of Marketing Research 11 (August), 286-294.

Dalen, J. van, J. Koerts and A.R. Thurik, 1987. The analysis of demand and supply factors in retailing using a disequilibrium model. Report 8712/A, Econometric Institute. Rotterdam: Erasmus University.

Fair, R.C. and D.M. Jaffee, 1972. Methods of estimation for markets in disequilibrium. Econometrica 40, 497-514.

Farris, P.W. and M.S. Albion, 1980. The impact of advertising on the price of consumer products. Journal of Marketing 44 (Summer), 17-35.

Gatignon, H., 1984. Competition as a moderator of the effect of advertising on sales. Journal of Marketing Research 21 (November), 387-398.

Kiefer, N.M., 1980. A note on regime classification in disequilibrium models. Review of Economic Studies 47, 637-639.

Kooiman, P., H.K. van Dijk and A.R. Thurik, 1985. Likelihood diagnostics and Bayesian analysis of a micro-economic disequilibrium model for retail services. Journal of Econometrics 29. nos. 1/2, 121-148.

Laffont, J.J. and R. Garcia, 1977. Disequilibrium econometrics for business loans. Econometrica 45, 1187-1204.

Leone, P. and R.L. Schultz, 1980. A study of marketing generalizations. Journal of Marketing 44 (Winter), 10-18.

Maddala, G.S., 1983. Limited-dependent and qualitative variables in econometrics. Cambridge: Cambridge University Press.

Nooteboom, B., 1982. A new theory of retailing costs. European Economic Review 17, 163-186.

Nooteboom, B., 1987. Threshold costs in service industries. Service Industries Journal 7, no. 1, 65-76.

Parsons, L.J. and R.L. Schultz, 1976. Marketing models and econometric research. New York: North-Holland.

Rosen, H.S. and R.E. Quandt, 1978. Estimation of a disequilibrium aggregate labour market. Review of Economics and Statistics 60, 371-379.

Sexton, D.E., 1970. Estimating marketing policy effects on sales of a frequently purchased product. Journal of Marketing Research 7 (August), 338-347.

Thurik, A.R. and A. Kleijweg. 1986. Procyclical retail labour productivity. Bulletin of Economic Research 38, no. 2, 169-175.

Thurik, A.R. and I. Koerts, 1984a. On the use of supermarket floorspace and its efficiency. In: Franco Angeli (ed.), Economics of Distribution. Milano: Franco Angeli, 387-445.

Thurik, A.R. and J. Koerts, 1984b. Analysis of the use of retail floorspace. International Small Business Journal 2, no. 2, 35-47.

Thurik, A.R. and P. Kooiman, 1986. Modelling retail floorspace productivity. Journal of Retailing 62, no. 4, 431-445. 